\title{
The Impact of Remittances on Children's Educational Attainment: Evidence from Egypt
}

\author{
Mina Sami Ayad \\ $\mathrm{PhD}$, Assistant Professor of Economics, American University in Cairo, Egypt
}

\section{Aliaa Abd El-Aziz}

Master of Arts in Economics, American University in Cairo, Egypt

\begin{abstract}
People often migrate in order to improve their family's standard of living. International migration is a widespread phenomenon among Egyptians and remittances can play an important role in alleviating household budget constraints. How do Egyptians invest their income received from remittances? Do remittances act as a significant tool to relax budget constraints for the household sector? Can we capture a relevant impact of the remittances on the education level in Egypt?

The purpose of this study is to examine the impact of remittances on the level of educational attainment of children between ages 6-21 in Egypt. We distinguish this impact among two categories of individuals according to their age: the school aged individuals and the university aged persons.

Two important contributions can be highlighted from our study: First, to the authors' knowledge, this is the first study that provides information on how do people invest their income received from remittances in Egypt, especially after the $25^{\text {th }}$ of January revolution. Second, it measures the impact of remittances on educational attainment rather than school enrollment rates, as adopted in the previous studies.

Using the latest available dataset on Egypt that includes detailed information on households' socioeconomic background and migration, the Egypt Labor Market Panel Survey (ELMPS, 2012), we imply an Ordered Probit Model using an Instrumental Variable (IV) approach to estimate the impact of remittance receipt on educational attainment. Findings show that remittances relax budget constraints positively impacting the educational attainment of university-aged youth. However, empirical results do not find any impact of remittances the school-aged individuals.
\end{abstract}

Keywords: Households, Remittances, Education.

JEL Classification: J61, O15, F22, F24.

(C) The Authors, 2018. This article is published with open access at Sumy State University.

\section{Introduction}

According to Egypt Labor Market Panel Survey 2012 (ELMPS), the number of Egyptian migrants follows, on average, an increasing trend over the period 1945-2011. The dataset shows that Egyptians have been tremendously migrating, especially to oil-rich Arab countries, temporarily or permanently. This fact is associated with a significant increase in the amount of inward remittances. The World Bank statistics indicate that the amount of inward remittances has substantially increasing over the period 1980-2015 from 2.69 Billion of dollars to reach 16.59 Billion of dollars, which actually represent approximately 5 percent of the Egyptian's GDP.

The previous literature provides a substantial analysis on the impact of remittances on the receiving countries. Three main issues can be highlighted: First, previous studies show that remittances affect income distribution, education, poverty alleviation, as well as individual welfare (Taylor and Wyatt (1996), Milanovic (1987)). In fact, those questions are very crucial to governments, especially in developing countries including Egypt. Second, other studies show that remittances have a significant impact on the macroeconomic indicators such as employment, productivity, and growth (Ratha, 2003). Finally, remittances are considered as stable foreign exchange source relative to other capital flows in some countries and might substantially impact the trade balance and current account (Buch and Kuckulenz, 2004).

Despite the important upward trends in the number Egyptian migrants and the important levels of remittances received by the Egyptian households, the impact of remittances on different socio-economic indicators, especially the education level, is still not covered by a comprehensive account (Nassar, 2005). How do Egyptians 
invest their income received from remittances? Do remittances act as a tool to relax budget constraints for the household sector? Can we capture a significant effect of the remittances on the education level in Egypt?

The effect of remittances on the education level has important implications, especially on the structure of the Egyptian labor market on the long-run. On one hand, if remittances are driven to short-run household consumption, it may decrease the level of productivity as it may represent important wage differential for the households that makes the Egyptian labor market unattractive (Acosta, Lartey and Mandelman, 2009). On the other hand, if remittances are driven to long-run productive investments (education) rather than consumption, it may boost the productivity levels and the number skilled labor in the Egyptian market.

This paper uses the Egypt Labor Market Panel Survey 2012 (ELMPS). This dataset is a nationally representative and comprehensive household survey carried out by the Economic Research Forum (ERF) in cooperation with Egypt's Central Agency for Public Mobilization and Statistics (CAPMAS). This survey is the first and most comprehensive source of publicly available micro data on labor market and human resource development in Egypt.

Two important contributions can be highlighted from our study: First, it is the first study that provides information on how do people invest their income received from remittances in Egypt, especially after the $25^{\text {th }}$ of January revolution using a novel dataset. Second, it is the first study that measures the impact of remittances on educational attainment rather than school enrollment rates. In Egypt, school enrolment rates can be a misleading indicator for the education level as it does not prove good evidence that the individual is getting educated. High school enrolment rates is not necessarily associated with high education levels as cash transfer programs provided by the Egyptian Government may boost school enrolment rates instead of education levels. On the other hand, educational attainment levels is a more robust measurement of the education level as it is measured post receiving the degree attained.

According to the literature, econometric strategy that aims to find the effect of remittances on educational attainment faces a significant problem of endogeneity. Remittances are additional sources of income, and as such relax budget constraints of households that may be preventing children from school attainment. Moreover, migrating can be a result of wanting to send children to school and needing extra income to do so. Thus, parents who care more about their children may migrate precisely in order to earn more income to pay for their children's education. In order to overcome this problem, an IV-ordered probit model that instruments the remittances by the historical migration at the shyakha (small village in Egypt) level has been implemented. This information is available at Census 2006 dataset carried out by CAPMAS. This Instrumental Variable is the most widely used in the literature in order to overcome this problem (Calero et al. (2009), Borromeo (2012), ElBadawy and Roushdy (2010)). Our results show that remittances relax budget constraints and positively impact educational attainment of university-aged youth.

The study is organized as follows: Section 2 presents the ELMPS data. Stylized facts regarding remittances and education in Egypt are presented Section 3. Section 4 describes the empirical methodology and main variables of interest. Results of estimations follow in Section 5 and concluding remarks are in Section 6.

\section{ELMPS database}

The paper uses the data from the Egyptian Labor Market Panel Survey (ELMPS) 2012. It is a nationally representative and comprehensive household survey carried out by the Economic Research Forum (ERF) in cooperation with Egypt's Central Agency for Public Mobilization and Statistics (CAPMAS). This survey is the first and most comprehensive source of publicly available micro data on labor market and human resource development in Egypt. The 2012 round is the third round carried out of this survey after a first and second round in 1998 and 2006 (Assaad and Krafft, 2013).

The ELMPS covers a wide range of topics related to economic characteristics, social background, as well as migration. These topics include: labor force participation, employment, unemployment, earnings, parental background, education, housing, access to services, residential mobility, migration and remittances, time use, marriage patterns and costs, fertility, women's decision making and empowerment, savings and borrowing behavior, and the operation of household enterprises and farms. The duration of the field work of the survey was from March to June 2012. The final sample of the ELMPS was 12,060 households, including 6,752 households from 2006 sample, 3,308 new households that emerged from these households, and 2,000 households as a refresher sample (Assaad and Krafft, 2013). 
Table 1. Educational attainment in ELMPS-2012

\begin{tabular}{|c|c|l|}
\hline Educational Attainment Level & Order & \multicolumn{1}{|c|}{ Definition } \\
\hline Illiterate & 1 & Illiterate \\
\hline Reads \& Writes & 2 & Reads and writes without any diploma \\
\hline Less than Intermediate & 3 & Primary and Middle School \\
\hline Intermediate & 4 & Secondary School \\
\hline Above Intermediate & 5 & Post Secondary School \\
\hline University & 6 & University and above \\
\hline
\end{tabular}

Source: ELMPS, 2012.

The ELMPS dataset provides information of whether the household is regularly receiving remittances or not during the past twelve months. In remittance receiving households, $54 \%$ of individuals are females. Mean of the households is 6 individuals per household. The total number of observations includes $71 \%$ in the schoolaged group and the rest in the university-aged group. There are 12,697 observations in the non-remittance receiving pool, with $49 \%$ females and same household size mean as remittance receiving households. $68 \%$ of these individuals lie within the school-aged range, whilst the rest are university aged. The mean age of all observations whether remittance receiving or non-remittance receiving is 13 years of age.

Table 2. Individual characteristics

\begin{tabular}{|c|c|c|}
\hline & In Remittance Receiving Households & In Non-Remittance Receiving Households \\
\hline Female Proportion (\%) & 54 & 49 \\
\hline Age in Years (mean) & 13 & 13 \\
\hline Household Size (mean) & 6 & 6 \\
\hline School-aged number of observations & 930 & 8,737 \\
\hline University-aged number of observations & 379 & 3,960 \\
\hline Total Number of Observations & 1309 & 12,697 \\
\hline
\end{tabular}

Source: ELMPS, 2012.

Overall, there is a lag in educational attainment with respect to age. It was observed from the ELMPS dataset that there is no standard age for a given education level. There is important variance between the children's age for a given education level. We observed that the age of children enrolled in school with respect to education levels is always higher. Probably parents' illiteracy and poverty is the main reason of this phenomena. Of all the school-aged individuals, the observations are mostly skewed towards having no diploma and being in primary school, which shows a lag, as this age group has individuals distributed across all schooling levels. This is also the case with university aged group, as they are more concentrated in middle school or primary school, when they should be in university. The total number of observations is clustered in the second and third orders of educational attainment level because of the high number of school aged individuals in the data. This is evident in both remittance and non-remittance receiving households. The monthly average amount of remittances received across all households is 7,700 EGP. This amount is ten times higher than the Egyptian minimum wage in 2012.

Table 3. Individual characteristics by level of education attainment of remittance receiving households

\begin{tabular}{|c|c|c|c|c|c|c|}
\hline Educational Attainment Level & 1 & 2 & 3 & 4 & 5 & 6 \\
\hline Ages 6-21 Observations & 84 & 602 & 417 & 196 & 5 & 5 \\
\hline Proportion $(\%)$ & 6 & 46 & 33 & 15 & 0.38 & 0.38 \\
\hline Ages 6-16 Observations & 57 & 592 & 279 & 2 & -- & -- \\
\hline Proportion $(\%)$ & 6 & 64 & 30 & 0.2 & 0 & 0 \\
\hline Ages 17-21Observations & 27 & 10 & 138 & 194 & 5 & 5 \\
\hline Proportion $(\%)$ & 7 & 4 & 36 & 51 & 1 & 1 \\
\hline Average Amount Received Month (EGP) & 3,696 & 4,709 & 7,740 & 12,630 & 5,441 & 8,816 \\
\hline Average Household Size & 6 & 6 & 6 & 5 & 5 & 4 \\
\hline \multicolumn{7}{|c|}{ Parent's education } \\
\hline Mother's Education Level (Mean) & 3 & 4 & 4 & 4 & 4 & 5 \\
\hline Father's Education Level (Mean) & 3 & 4 & 4 & 4 & 4 & 5 \\
\hline
\end{tabular}

Source: ELMPS, 2012.

Educational attainment with respect to regional distribution is generally higher in urban regions while in rural regions individuals are mostly uneducated. It is worth mentioning that, Cairo is the most remittance receiving Region of all regions. 
Table 4. Regional education attainment (on average)

\begin{tabular}{|c|c|c|}
\hline Region & In Remittance Receiving & In Non-remittance Receiving \\
\hline Gr. Cairo & 4.3 & 4.6 \\
\hline Alex \& Suez Canal & 4.5 & 4.5 \\
\hline Urban Lower & 4.3 & 4.3 \\
\hline Urban Upper & 4.0 & 4.2 \\
\hline Rural Lower & 3.8 & 3.9 \\
\hline Rural Upper & 3.3 & 3.5 \\
\hline
\end{tabular}

Source: ELMPS, 2012

\section{Do remittances relax budget constraints?}

\subsection{Education and parental wealth}

In poor areas, there is always the opportunity cost of children's time, in the sense that, children can actually be increasing income of the household by entering child labor activities, instead of getting education and being an expense to the family. Girls can have a different kind of cost, which is a reputational cost, when continuing education in a mixed school with boys. On top of all these costs, the education quality and school quality is low, thus, by time and as children age and costs rise, parents may decide to drop their children from the education system. Focusing on direct costs of education and basic education completion, it is clear that parental wealth is a high determinant of basic education completion. To be able to calculate this relation, we used the wealth quintiles provided by the ELMPS dataset and matched it with educational attainment levels to get the following results. Children from richer households have higher possibilities of completing education, than of lower income households. Only $61 \%$ of boys and $64 \%$ of girls from the poorest fifth quintile have a chance to complete basic education. On the other hand, nearly $100 \%$ of boys and girls in the richest fifth quintile have a chance of completing basic education (see Figure 2).

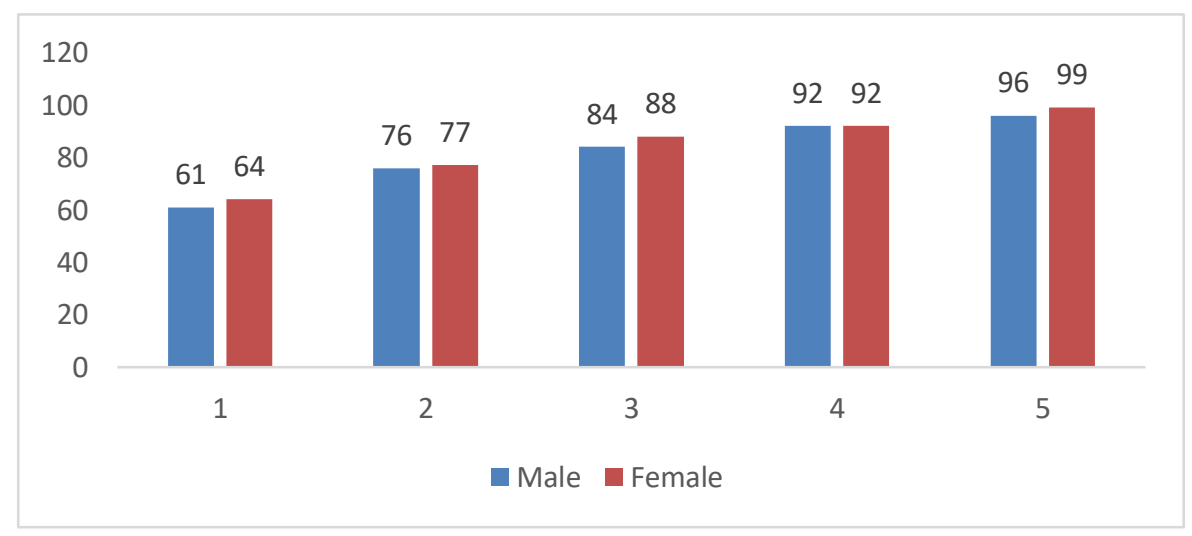

Figure 1. Percentage of basic education completion with respect to parental wealth

Source: ELMPS, 2012.

\subsection{Education and budget constraints}

Since the quality of public education is generally regarded as low, parents often resort to a learning support strategy that is very common, private tutoring. Private tutoring is common at all education levels, and as children grow up, the fraction of children resorting to private tutoring increases. Another phenomenon which increases demand for private lessons is that some of the school teachers, supply private tutoring lessons, this drives a further poorer education to push children into taking private lessons with them. This further diminishes the quality of school education and raises the cost of overall education. It has been available at all regions, and in all socio-economic levels of households. Because it is expensive, there is a strong relationship between private tutoring and the socio-economic background of the children. $57 \%$ of children from the wealthiest quintile take private lessons, and $34 \%$ of the poorest quintile take private lessons (see figure 3 ). This shows that even the poorest households, have needed to resort to paying extra costs in order to get a better education for their children. In some cases, resorting to one type of learning support is not enough, and that leads the child to depend on another type of learning support. If public education was sufficient on its own to ensure a 
reasonable schooling outcome, parents would have not resorted to investing money in another educational supplement (Assaad and Krafft, 2015).

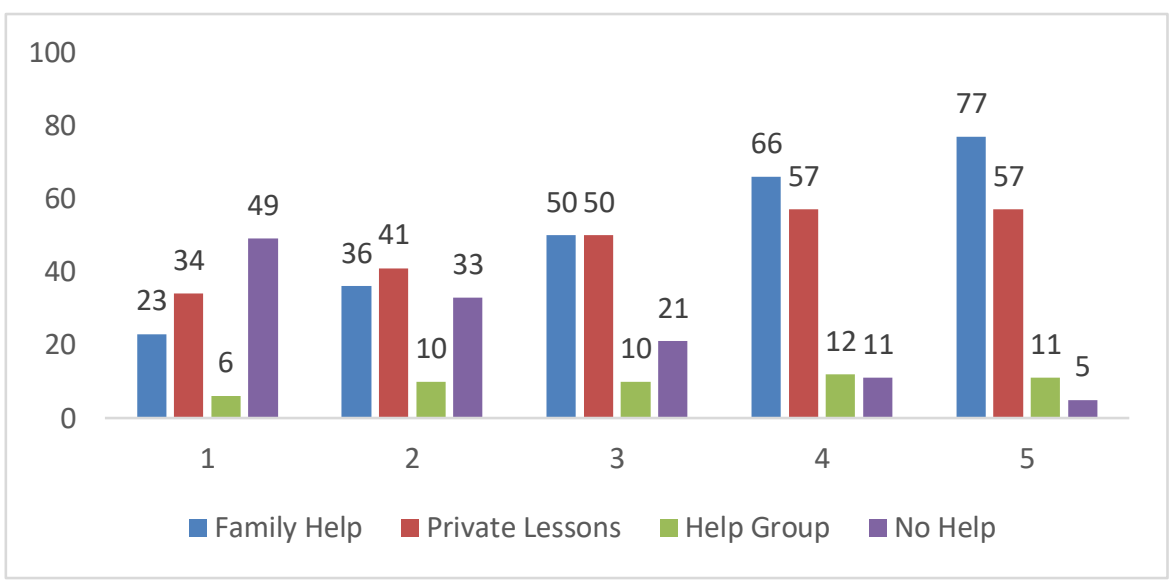

Figure 2. Percentage of individuals receiving learning support

Source: ELMPS, 2012.

To sum-up, overall, these figures suggest that educational attainment depends highly on parental wealth or household income in general. Egyptians face an unbalanced, poor educational system, despite the reforms the government has been trying to implement, and the policy of free education for all. This is mainly driven by how the government has been focusing on providing free basic education and expanding the education system despite its low cost. This resulted in Egypt ranking low with respect with respect to quality of primary education, according to the Global Competitiveness Report for 2013-2014 (World Economic Forum 2013).

\section{Econometric estimation}

As mentioned above, the objective of this study is to find the effect of remittances on the education levels. As our dependent variable (educational level) is categorical from level one to level six, as defined in the ELMPS database, we note that any econometric methodology that proposes a linear regression will lead to biased results.

Therefore, our empirical estimation follows McKelvey \& Zovoina (1975) as an ordered probit model will be implemented. The ordered probit model will be appropriate for this situation as our dependent variable is categorical and qualitative.

We consider a model characterized by a latent regression in which $y^{*}$ is unobserved :

$y^{*}=X^{\prime} \beta+\varepsilon$

On one hand, $X^{\prime} \beta$ represents the matrix of explanatory variables including the remittances. On the other hand, $\varepsilon$ represents the unobservable factors and its assumed to be Independently Identically distributed. Moreover, we assume that $\varepsilon$ follows a normal distribution with a mean zero and variance of unity.

We assume that our dependent variable y can be classified according to six main categories that represent the education levels:

$y=\left\{\begin{array}{lr}0 \text { if } y^{*}=0 & \begin{array}{r}\text { Illetrate } \\ 1 \text { if } 0<y^{*} \leq \mu_{1}\end{array} \\ 2 \text { if } \mu_{1}<y^{*} \leq \mu_{2} & \text { Primary and Middle school } \\ 3 \text { if } \mu_{2}<y^{*} \leq \mu_{3} & \text { Secondary schooling } \\ 4 \text { if } \mu_{3}<y^{*} \leq \mu_{4} & \text { Post Secondary schooling } \\ 5 \text { if } \mu_{4}<y^{*} \leq \mu_{5} & \text { University and above }\end{array}\right.$

The $\mu_{i}$ are unknown threshold parameters that determine the estimations for different values of observed $\mathrm{y}$. They can be interpreted as constants.

As mentioned above, the literature proposes a problem of endogeneity between the education decision and the remittances. Perhaps, parents who are more educated about their children's education will take the decision to migrate in order to earn more income to afford their children's education. On the other hand, the decision of 
being educated can be taken when remittances are present and there is extra income in the household that would support the decision.

In order to avoid this problem, an instrumental variable approach has been implemented. The historical migration rates share of households with migrants at a particular shyakha (small village in Egypt) has been developed. This variable is suitable in the case of Egypt, as it is very common that Egyptians' choice of migrating is affected by the social communities around them, and that if they find support from relatives and people for their communities in potential migration countries, it will be much easier for them to take a decision to migrate (ElBadawy and Roushdy, 2010).

$X_{1}=\Omega Z+v_{i}$

$Z$ is considered as the instrumental variable that will be implemented in order to estimates the remittances variable $\left(X_{1}\right)$ extracted from the matrix of the explanatory variables $X^{\prime} \beta$.

The marginal effects for the independent variables including the remittances has been reported in all of our regressions

Finally, we can write our model as follows:

$$
\begin{aligned}
& E d u_{i, s}=\text { Remitt }_{1 i, s} \beta_{1}+X_{2 i, s} \gamma_{2}+\varepsilon_{i} \\
& \text { Remitt }_{i}=\text { Mig Pct }_{1} \Pi_{1}+v_{i}
\end{aligned}
$$

We note that the dependent variable differs in each regression according to age range and is defined as follows:

Table 5. Variable definitions

\begin{tabular}{|l|l|}
\hline Variable & Variable Definitions \\
\hline Remittance Receipt & Remittances is a Binary variable, showing whether the household receives remittances or not \\
\hline Household Size & Size of Household the Individual is living in (number of individuals) \\
\hline Sex & Gender of Individual \\
\hline Age & Age of all children (6-21) \\
\hline Age Squared & Value of age squared \\
\hline Father Education & Education level of the individual's father in education attainment level \\
\hline Mother Education & Education level of the individual's mother in education attainment level \\
\hline Father Work & Whether father is in a paid job or not \\
\hline Enterprise Ownership & Whether the family of individual owns an enterprise or not \\
\hline Capital & Whether the capital the individual's family owns is greater than 10k EGP or not \\
\hline & \\
\hline Regions & $\begin{array}{l}\text { It is divided as follows: Greater Cairo, Alexandria \& Suez Canal, Urban Lower, Urban Upper, Rural } \\
\text { Lower, Rural Upper }\end{array}$ \\
\hline Migration percentage & $\begin{array}{l}\text { Percentage of migrations in social networks of families and friends who have previously migrated in } \\
\text { a certain Shyakha. }\end{array}$ \\
\hline
\end{tabular}

The sample includes all individuals aged from 6-21 who are in remittance receiving households and otherwise. This is the most relevant age group when looking at educational attainment levels, and what is typically used in the literature. In the structure of the Egyptian education system, children typically enter primary school at the age of 6, and finish high school by the age of 17, after that they either continue education directly after or in poor areas go to work (Assaad and Krafft, 2015). Remittances include both monetary and non-monetary value assistance. Finally, we used the education variable in the dataset as the dependent variable which is divided into the 6 categories of educational attainment: illiterate, reads \& writes, less than intermediate, intermediate, above intermediate, university and above. As mentioned above, the dataset reports whether the household is regularly receiving remittances or not during the past twelve months. Empirical estimations suggest that receiving an amount of remittances in the previous year has a significant impact on the education levels.

The analysis is carried out for three different age groups. These are first the full sample including all children aged 6-21. This is then divided into two different sub groups, school aged children (6-16) and university aged youth (17-21). In the school-aged sub group, we excluded all educational attainment levels higher than the 
secondary school as none of the individuals lying in this age group would have a higher educational attainment level. As for the university-aged sub group, all educational attainment levels are included ${ }^{1}$.

\section{Empirical results}

The empirical estimation assesses the impact of remittances on education attainment levels of children aged 621, and then sub-grouped by age: school aged (6-16) and university aged (17-21), in Egypt, respectively. The estimation was tested on these age groups, differentiating the households on whether they are remittance receiving or not. We note that the results between Standard Ordered Probit model and IV-Ordered Probit model are critically interesting (Table $6 \&$ Table A.3. $)^{2}$. The Standard Ordered Probit model results do not estimate any impact of remittances on the education level for any age class nor the aggregated ages. However, the endogeinty between remittances and education attainment is questioned by the first stage regression as mentioned before in the previous section.

In table 6, exogeneity of the instrumented variable to the outcome variable is initially tested. The results of this test (atanhrho) show that the IV variable migration percentage is significant in all regressions across all age groups. These tests prove that the instrumental variable used is both strongly correlated with the instrumented variable and is not correlated with the error term in the second stage regression.

Remittances have a positive significant effect on the educational attainment level of children aged 6-21 living in households receiving remittances in Egypt. Table 6 includes the results for the regressions run on the educational attainment level of children aged 6-21 in remittance receiving households. We note a positive significant effect between remittance receipt and educational attainment levels. This suggests that budget constraints limit educational attainment, as remittances play a role of relaxing budget constraints, and it is shown that people would invest in the educational attainment of their children if they can afford to do so.

Age is a statistically significant variable and is positively related to the educational attainment level of children in remittance receiving households. It is not surprising that the age level increase the educational attainment level of children in remittance receiving households would increase too. Since remittance receipt is statistically significant to child educational attainment level, then as children in remittance receiving households grow, their educational attainment level will get higher.

As for parents' education, mother's education is statistically significant and has a positive impact on children's educational attainment. Having an educated mother in the household, would help children in their studying, which is a common type of learning support, family help, according to Assaad and Krafft (2015). Fathers' education is also positive and is shown to be significant to child educational attainment level. This also makes sense since the father is mainly the provider of the family, and him being convinced about the importance of education, would influence him more to spend on educational attainment of the children in the household. That being said, it is clear that the parents' education is essential in households in Egypt, and has an important relationship with the educational attainment of the children. Educated parents may have a better chance in having better jobs, thus earning more income to be able to educate their children. On the other hand, if parents are not educated, they would have lower income jobs, further increasing pressure on resource constraints. In addition to that, none of the parents would have the ability to help or follow up with the children on their studying, which in the case of Egypt is essential, as quality of teachers in public schools has not been very high (OECD 2015).

Now moving to the sub groups of age, starting with school aged children, shows that remittance receipt has no statistical significance on school aged children. The estimations here were run on 9,647 observations and are aged between 6-16 years of age. Moreover, when running this estimation, any educational attainment level that was higher than high school was excluded, as normally, none of the individuals in this age group would have any higher educational attainment level.

When estimating the effect of remittance receipt on the educational attainment level of University aged group, it is indicated to be significant with a positive relationship to educational attainment. There is a high in propensity of having a higher educational attainment level at this age group if the household is a remittance receiving one.

Most of the significant variables in this regression have also been shown to be significant when estimating the results on the whole age group. The household size is statistically significant with a negative relation to the

\footnotetext{
${ }^{1}$ See appendix for the table of descriptive statistics (Table A.1., Table A.2.) regarding the final sample of the regressions.

${ }^{2}$ See appendix for the results of first stage standard Ordered Probit model.
} 
educational attainment of individuals in this group. Important number members within the same Household lead to a greater pressure on household resources. Thus, referring to the conceptual framework by McKenzie and Rapoport (2006) of remittances and budget constraints, as the costs of educating each child increases there is a less likely chance of each child attaining a higher level of education due to the binding budget constraint, household resources. Moreover, age of individuals is also significant and positively correlated with educational attainment level in this case. Parents' education is also significant in this case, for mother's and father's level of education with a positive effect on educational attainment level of university aged youth.

Table 6. Impact of Remittances on Each Age Group (IV-Ordered Probit Outcomes)

\begin{tabular}{|c|c|c|c|}
\hline & School-aged & University-aged & All Ages \\
\hline Remittance Receipt & $\begin{array}{r}-0.019 \\
(0.054) \\
\end{array}$ & $\begin{array}{c}0.135^{* *} \\
(0.067) \\
\end{array}$ & $\begin{array}{c}0.081 * * \\
(0.038) \\
\end{array}$ \\
\hline Household Size & $\begin{array}{c}-0.012 \\
(0.008) \\
\end{array}$ & $\begin{array}{c}-0.016 * * \\
(0.008)\end{array}$ & $\begin{array}{c}-0.005 \\
(0.005) \\
\end{array}$ \\
\hline Female & $\begin{array}{c}0.030 \\
(0.028)\end{array}$ & $\begin{array}{l}-0.026 \\
(0.035)\end{array}$ & $\begin{array}{l}-0.012 \\
(0.019)\end{array}$ \\
\hline Age & $\begin{array}{c}-0.128 * * * \\
(0.038)\end{array}$ & $\begin{array}{c}2.458 * * * \\
(0.319)\end{array}$ & $\begin{array}{c}0.170 * * * * \\
(0.015)\end{array}$ \\
\hline Age Squared & $\begin{array}{c}0.023 * * * \\
(0.002)\end{array}$ & $\begin{array}{c}-0.056 * * * \\
(0.008)\end{array}$ & $\begin{array}{c}0.003 * * * * \\
(0.001)\end{array}$ \\
\hline Father's Level of Education & $\begin{array}{c}0.089 * * * \\
(0.011)\end{array}$ & $\begin{array}{c}0.192 * * * \\
(0.015)\end{array}$ & $\begin{array}{c}0.121 * * * * \\
(0.008)\end{array}$ \\
\hline Mother's Level of Education & $\begin{array}{c}0.039 * * * \\
(0.012)\end{array}$ & $\begin{array}{c}0.092 * * * \\
(0.017)\end{array}$ & $\begin{array}{c}0.036 * * * * \\
(0.009)\end{array}$ \\
\hline Father's Work & $\begin{array}{c}0.006 \\
(0.060)\end{array}$ & $\begin{array}{c}0.064 \\
(0.067)\end{array}$ & $\begin{array}{c}0.011 \\
(0.040)\end{array}$ \\
\hline Family Enterprise & $\begin{array}{c}0.013 \\
(0.039)\end{array}$ & $\begin{array}{c}0.007 \\
(0.051)\end{array}$ & $\begin{array}{c}0.016 \\
(0.028)\end{array}$ \\
\hline Capital & $\begin{array}{l}-0.036 \\
(0.066)\end{array}$ & $\begin{array}{l}-0.020 \\
(0.084)\end{array}$ & $\begin{array}{l}-0.011 \\
(0.046)\end{array}$ \\
\hline Alex \& Suez Canal & $\begin{array}{c}0.086 \\
(0.074)\end{array}$ & $\begin{array}{c}0.028 \\
(0.088)\end{array}$ & $\begin{array}{c}0.031 \\
(0.050)\end{array}$ \\
\hline Urban Lower & $\begin{array}{c}0.091 \\
(0.065)\end{array}$ & $\begin{array}{c}0.125 \\
(0.081)\end{array}$ & $\begin{array}{c}0.063 \\
(0.045)\end{array}$ \\
\hline Urban Upper & $\begin{array}{l}0.100^{*} \\
(0.061)\end{array}$ & $\begin{array}{c}0.213 * * * \\
(0.076)\end{array}$ & $\begin{array}{c}0.084 * * \\
(0.042)\end{array}$ \\
\hline Rural Lower & $\begin{array}{c}0.209 * * * \\
(0.055)\end{array}$ & $\begin{array}{c}0.234 * * * \\
(0.070)\end{array}$ & $\begin{array}{c}0.133 * * * * \\
(0.038)\end{array}$ \\
\hline Rural Upper & $\begin{array}{l}-0.048 \\
(0.057)\end{array}$ & $\begin{array}{l}-0.059 \\
(0.071)\end{array}$ & $\begin{array}{c}-0.113 * * * \\
(0.039)\end{array}$ \\
\hline Mig. Percentage (IV) & $\begin{array}{c}0.017 * * * \\
(0.005)\end{array}$ & $\begin{array}{c}0.019 * * \\
(0.010)\end{array}$ & $\begin{array}{c}0.017 * * * * \\
(0.005)\end{array}$ \\
\hline Exogeneity of IV & Yes & Yes & Yes \\
\hline Log-likelihood & -5382 & -4307 & -12945 \\
\hline
\end{tabular}

Notes: Significance Levels $* * * \mathrm{p}<0.01, * * \mathrm{p}<0.05, * \mathrm{p}<0.1$, Robust Standard Error are provided.

Reference Category for Regional Variable: Greater Cairo. 


\section{Conclusion}

The literature has shown different results on how remittances affect human capital development. The differences in outcomes depend on many factors regarding household, parents', and individual's characteristics. This paper examines the impact of remittances on child educational attainment in Egypt.

To our knowledge this is the first study that measures the impact of remittances on educational attainment rather than school enrollment rates. It uses 6-21 aged individuals, and regress remittances impact of children aged between 6-21.

The findings suggest that credit constraints and limited household resources are an obstacle to higher levels of educational attainment. The results show that remittance receipt has a statistically significant impact on the educational attainment level of children aged 6-21 in Egypt. Parent's education in the household is an important factor positively affecting the educational attainment of children. Moreover, after dividing the age groups, remittances are found not to be significant on the educational attainment of school aged children (6-16). On the other hand, it was shown to be significant and positively affecting university aged youth (17-21). There is a negative and significant relationship between household size and educational attainment of university-aged youth indicating that as household size increases, it is less likely that children would get educated.

Like other studies, this study has had its limitations. This study could have looked further into the differential impacts of gender. The impact of remittances may differ when looking at gender as the labor market differs for both genders. The opportunity cost of getting educated is different for girls than for boys. Another limitation is that the study could have further analyzed household characteristics, to see what drives some households to invest in education while others don't. These characteristics may include, household head's relation to children, household's head's gender, and who is the migrant within the household.

Given the positive role remittances can play, the Egyptian government should work on managing migration processes in order to improve the standard of living of individuals. That is because remittances are invested in one way or another. In this study, the effect of remittances on child educational attainment levels suggests that Egyptians invest in human capital attainment when gaining an additional income. The Egyptian government should also work on minimizing remittance transfer costs and encourage people to transfer remittances formally for banks to be able to make use of these foreign exchange deposits.

The positive role of remittances and migration in developing can be substantial. Building on the empirical work conducted in this study, there is more research that could be done to further understand how remittances can play a role in human capital development and economic development. Additional work could look at the differential impact of migration and remittances across genders. Moreover, child labor can be added as another dependent variable, as often children not in school are working. The role of budget constraints in household behavior can be further analyzed. Egypt is running a conditional cash transfer program; thus rigorous policy evaluations of the program could shed light on Egyptian households' behavior under constraints.

\section{References}

1. Acosta, P. (2006). Labor Supply, School Attendance, and Remittances from International Migration: The Case of El Salvador. The World Bank 3903. Web. 13 Dec. 2016.

2. Assaad, R., and Caroline, K. (2015). Is Free Basic Education in Egypt a reality or a myth? International Journal of Educational Development, 4, 16-30. Web. 29 Apr. 2017.

3. Assaad, R., and Caroline K. (2013). The Egypt labor market panel survey: introducing the 2012 round. IZA Journal of Labor \& Development, 2(1), p. 8.

4. Binzel, C., and Assaad, R. (2009). The Impact of International Migration and Remittances on the LaborSupply Behavior of Those Left Behind: Evidence from Egypt. Unpublished Manuscript. n. pag. Web. 14 Dec. 2016.

5. Borromeo, M. and Roberto, V. (2012). Remittances and the Educational Attainment of Children in the Philippines. Upsala (750). Web. 29 Apr. 2017.

6. Buch, C. and Kuckulenz, A. (2004), Worker Remittances and Capital Flows to Developing Countries. Centre for European Economic Research (ZEW) Discussion Paper No. 04 31, ZEW, Mannheim

7. Calero, C., and Arjun, S. (2009). Remittances, Liquidity Constraints and Human Capital Investment in Ecuador. World Development, 37(6), 1143-154. Web. 14 Dec. 2016. 
8. ElBadawy, A., and Roushdy, R. (2010). Impact of International Migration and Remittances on Child Schooling and Child Work: The Case of Egypt. Working Paper Economics Research Forum 545, n. pag. Web. 14 Dec. 2016.

9. Koska, O., Periha, O., Selim, C., and Areal-Tur, Andres (2013). International Migration, Remittances, and the Human Capital Formation of Egyptian Children. International Review of Economics \& Finance, 28, 38-50. Web. 14 Dec. 2016.

10. McKenzie, D. and Rapoport, H. (2006). Can Migration Reduce Educational Attainment? Evidence from Mexico. Policy Research Working Paper Series 3952. The World Bank. n. pag. Web. 14 Dec. 2016.

11. Milanovic, B. (1987): Remittances and income distribution. Journal of Economic Studies, 14(5), 24-37.

12. Nassar, H (2005). Migration, Transfer and Development in Egypt. CARIM Research Report. Web. 12 Dec. 2016.mi.

13. Ratha, D. (2003). Worker's Remittances: An Important and Stable Source of External Development Finance. Global Developing Finance 2003, World Bank, pp. 157-175.

14. Taylor, J., Wyatt, T. (1996). The shadow value of migrant remittances, income and inequality in a household-farm economy. Journal of Development Studies, 32, 899-912.

\section{Appendices}

Table 1. Summary statistics of variables

\begin{tabular}{|l|c|c|c|c|}
\hline \multicolumn{1}{|c|}{ Variable } & Median & Std. Dev. & Min & Max \\
\hline Education & 3 & 0.86 & 1 & 6 \\
\hline Age & 13 & 4.8 & 6 & 21 \\
\hline Household size & 5 & 2.3 & 1 & 18 \\
\hline
\end{tabular}

Table 2. Impact of Remittances on Each Age Group (Standard Ordered Probit Outcomes)

\begin{tabular}{|c|c|c|c|}
\hline & School-aged & University-aged & All Ages \\
\hline Remittance Receipt & $\begin{array}{l}0.0387 \\
(0.123)\end{array}$ & $\begin{array}{l}0.0193 \\
(0.107)\end{array}$ & $\begin{array}{c}0.0998 \\
(0.0799)\end{array}$ \\
\hline Household Size & $\begin{array}{c}-0.0512 * * \\
(0.0240)\end{array}$ & $\begin{array}{c}-0.0320 \\
(0.0297)\end{array}$ & $\begin{array}{c}-0.0355^{*} \\
(0.0190)\end{array}$ \\
\hline Female & $\begin{array}{l}0.0284 \\
(0.107)\end{array}$ & $\begin{array}{c}-0.00510 \\
(0.101)\end{array}$ & $\begin{array}{l}0.00967 \\
(0.0654)\end{array}$ \\
\hline Age & $\begin{array}{c}3.404 * * * \\
(1.272)\end{array}$ & $\begin{array}{c}0.620 \\
(0.509)\end{array}$ & $\begin{array}{c}0.423 * * * \\
(0.100)\end{array}$ \\
\hline Age Squared & $\begin{array}{c}-0.0786 * * \\
(0.0336)\end{array}$ & $\begin{array}{r}-0.00239 \\
(0.0209)\end{array}$ & $\begin{array}{c}-0.00355 \\
(0.00346)\end{array}$ \\
\hline Father's Level of Education & $\begin{array}{c}0.0956 * * \\
(0.0423)\end{array}$ & $\begin{array}{c}0.0383 \\
(0.0429)\end{array}$ & $\begin{array}{c}0.0775^{* * *} * \\
(0.0243)\end{array}$ \\
\hline Mother's Level of Education & $\begin{array}{c}0.174 * * * \\
(0.0449)\end{array}$ & $\begin{array}{c}0.115 * * * \\
(0.0343)\end{array}$ & $\begin{array}{c}0.0861 * * * \\
(0.0226)\end{array}$ \\
\hline Father's Work & $\begin{array}{c}0.313^{* *} \\
(0.158)\end{array}$ & $\begin{array}{c}0.112 \\
(0.198)\end{array}$ & $\begin{array}{l}0.207 * * \\
(0.0980)\end{array}$ \\
\hline Family Enterprise & $\begin{array}{c}-0.0646 \\
(0.428)\end{array}$ & $\begin{array}{c}0.886 \\
(0.540)\end{array}$ & $\begin{array}{c}0.241 \\
(0.311)\end{array}$ \\
\hline Capital & $\begin{array}{c}-0.824 * * \\
(0.325)\end{array}$ & $\begin{array}{l}0.0824 \\
(0.319)\end{array}$ & $\begin{array}{c}-0.415^{*} \\
(0.229)\end{array}$ \\
\hline Alex \& Suez Canal & $\begin{array}{c}0.523 \\
(0.372)\end{array}$ & $\begin{array}{l}0.0845 \\
(0.269)\end{array}$ & $\begin{array}{c}0.233 \\
(0.218)\end{array}$ \\
\hline Urban Lower & $\begin{array}{c}0.640 * * \\
(0.256)\end{array}$ & $\begin{array}{c}0.284 \\
(0.320)\end{array}$ & $\begin{array}{c}0.344 * * \\
(0.171)\end{array}$ \\
\hline Urban Upper & $\begin{array}{c}0.665 * * * \\
(0.249)\end{array}$ & $\begin{array}{c}0.296 \\
(0.269)\end{array}$ & $\begin{array}{c}0.368 * * \\
(0.153)\end{array}$ \\
\hline Rural Lower & $\begin{array}{c}0.610 * * * \\
(0.223)\end{array}$ & $\begin{array}{c}0.468 * * \\
(0.237)\end{array}$ & $\begin{array}{c}0.357 * * * \\
(0.132)\end{array}$ \\
\hline
\end{tabular}


Table 2 (cont.). Impact of Remittances on Each Age Group (Standard Ordered Probit Outcomes)

\begin{tabular}{|c|c|c|c|}
\hline & School-aged & University-aged & All Ages \\
\hline \multirow{2}{*}{ Rural Upper } & 0.335 & 0.328 & 0.206 \\
$(0.145)$ \\
\hline Log likelihood & $(0.246)$ & $(0.255)$ & -1058 \\
\hline
\end{tabular}

Notes: Significance Levels $* * * \mathrm{p}<0.01, * * \mathrm{p}<0.05,{ }^{*} \mathrm{p}<0.1$, Robust Standard Error are provided.

Reference Category for Regional Variable: Greater Cairo. 